\title{
Myteknusing tar tid
}

Antibiotika ble tidlig kalt «den magiske kulen» - et prosjektil som sparer venn og skader fiende (1). Ideelt sett skiller antibiotika perfekt mellom «oss» - våre sterile, rene og pene kropper - og «de andre» - bakterier som påføres kroppen utenfra og gjør den skitten og syk. Som på andre områder i livet er det fristende å skylde på «de andre» - og gripe til antibiotika.

Noen ganger stemmer det. Oppdagelsen av Helicobacter pylori som årsak til magesår medførte at sykdommen ble omdefinert fra psykosomatisk lidelse til infeksjonssykdom. Dette er en forlokkende modellhistorie for forskere, behandlere og pasienter som opplever et etiologisk underskudd for akkurat sin lidelse. Kroniske plager etter mulig flåttbitt, langvarige ryggsmerter og autisme er blitt hevdet å være det nye magesåret. Det er opprettet behandlingsinstitusjoner der man gir langvarig antibiotikabehandling mot disse plagene - utenom det etablerte helsevesenet.

Før eller siden kan vi oppdage et nytt «magesår» - men behandling med risiko for både individuelle og samfunnsmessige bivirkninger bør ikke etableres før effekt er dokumentert. Mytene rundt antibiotika ser ut til å oppføre seg på samme måte som antibiotikaresistensen selv - «easy to get, hard to lose» (2).

Denne typen udokumentert langvarig antibiotikabehandling har fått mye oppmerksomhet som årsak til resistensutvikling. Men de mindre spektakulære mytene rundt antibiotika er en større bidragsyter til unødvendig bruk. I det siste er det blitt tatt til orde for å knuse nettopp en slik hverdagsmyte: Man må alltid fullføre antibiotikakuren, ellers blir bakteriene resistente (3). Det er noe som skurrer med denne kommandoen, et formyndersk «Spis opp maten din!» selv om du er aldri så mett. Så lystrer da heller ikke pasientene - over halvparten av dem som får antibiotika for en nedre luftveisinfeksjon i allmennpraksis, fullfører ikke kuren (4).

Det finnes ingen dokumentasjon for påstanden. For å redusere risikoen for resistensutvikling bør totalbruken være så lav som mulig og andelen smalspektret antibiotika så høy som mulig (5). Lengden på en antibiotikakur bør derfor avgjøres av den kliniske effekten, kuren bør være akkurat lang nok til at man unngår terapisvikt og residiv. For å slippe unødvendig lange kurer i allmennpraksis er det to muligheter: enten forkorte anbefalt varighet eller anbefale pasientene å gjøre det de allerede gjør - kutte kuren når de føler seg friske.

Anbefalt varighet av en antibiotikakur er ganske tilfeldig bestemt den kan reflektere en lang og seig tradisjon eller være basert på produsentens avgjørelse $i$ tidlige legemiddelstudier (6). I en metaanalyse fant man at korte kurer i hovedsak har like god effekt som lange (7). Fremdeles mangler det imidlertid gode studier, og dem vi har, er er ofte gjort på mer bredspektret antibiotika enn det vi i Norge er så heldige å kunne bruke.

Den andre muligheten er altså å gi pasienten en rolle i vurderingen av sin infeksjonssykdom. Dette er prinsippet bak vent-og-se-resept - her får pasienten i oppgave å starte en antibiotikakur kun på visse kriterier. Flerfoldige studier viser at metoden gir en trygg reduksjon av antibiotikabruken, og de fleste pasienter og leger er fornøyd med den. Norske retningslinjer har derfor siden 2008 anbefalt vent-ogse-resept ved visse diagnoser og under visse forutsetninger (8). Dette har imidlertid vært en lang prosess, de første studiene på slike resepter er fra 1997. På tilsvarende vis kan også pasientene monitorere effekten av en antibiotikakur og avslutte når de føler seg friske. Men det skal mye til å anbefale en slik strategi for norske allmennleger før vi har studier som sier at den er trygg.

For å kvitte oss med skadelige antibiotikamyter og hindre nye fra å feste seg, trengs det først og fremst god dokumentasjon. I og med at $80 \%$ av all antibiotika forskrives i allmennpraksis (9), er det viktig å hente dokumentasjon derfra. Og fordi antibiotikaresistens og behandlingstradisjon varierer fra land til land, bør dokumentasjon hentes fra Norge. De 14 millioner årlige konsultasjonene i norsk allmennpraksis er sørgelig underutforsket. Det er her det store gross av diagnostikk og behandling skjer, likevel finnes det ingen etablerte systemer for klinisk forskning i allmennpraksis. Et allmennmedisinsk forskningsnettverk (10) vil neppe være like underholdende som det amerikanske faktaprogrammet MythBusters - men billigere og viktigere.

\section{Sigurd Høye}

sigurd.hoye@medisin.uio.no

Sigurd Høye (f. 1972) er postdoktor ved Antibiotikasenteret for primærmedisin, Avdeling for allmennmedisin, Universitetet i Oslo, allmennlege og medisinsk redaktør i Tidsskriftet (i permisjon). Han er også medlem av redaksjonen for Nasjonale faglige retningslinjer for antibiotikabruk i primærhelsetjenesten.

Forfatter har fylt ut ICMJE-skjemaet og oppgir ingen interessekonflikter.

\section{Litteratur}

1. Bud R. Penicillin. Triumph and Tragedy. New York: Oxford University Press, 2007.

2. Johnsen PJ, Townsend JP, Bøhn T et al. Factors affecting the reversal of antimicrobial-drug resistance. Lancet Infect Dis 2009; 9: 357-64.

3. Vil knuse «antibiotika-myte». Dagens Medisin 2017.

4. Francis NA, Gillespie D, Nuttall J et al. Antibiotics for acute cough: an international observational study of patient adherence in primary care. $\mathrm{Br} \mathrm{J}$ Gen Pract 2012; 62: e429-37

5. Antibiotikaresistens - kunnskapshull, utfordringer og aktuelle tiltak. Rapport fra tverrsektoriell ekspertgruppe. Oslo: Folkehelseinstituttet, 2014.

6. Gilbert L. No, you don't have to finish all your antibiotics. The Conversation 2015. http://theconversation.com/no-you-dont-have-to-finish-all-your-antibiotics38774 (5.5.2017)

7. Esposito S, Esposito I, Leone S. Considerations of antibiotic therapy duration in community-and hospital-acquired bacterial infections. J Antimicrob Chemother 2012; 67: 2570-5.

8. Nasjonal faglig retningslinje for antibiotikabruk i primærhelsetjenesten. Oslo: Helsedirektoratet, 2012. www. antibiotikaiallmennpraksis.no (5.5.2017).

9. NORM/NORM-VET. 2015. Usage of Antimicrobial Agents and Occurrence of Antimicrobial Resistance in Norway. Troms $\varnothing / O s l o: ~ N O R M / N O R M-V E T, 2016$.

10. Rørtveit G. Fremtidens primærhelsetjeneste - uten forskning? Tidsskr Nor Legeforen 2015; 135: 1219. 